\title{
Occupational Exposure to Metals and Serum Adiponectin Levels Among Shipyard Workers: A Cohort Study with Weighted Quantile Sum Regression Analyses
}

Chen-Jung Wu

Taoyuan Armed Forces General Hospital

A-Chuan Ho

National Defense Medical Center

Shih-Ya Chen

National Defense Medical Center

Chih-Hong Pan

NDMC: National Defense Medical Center

Hsiao-Chi Chuang

Taipei Medical University

Wei-Liang Chen

Tri-Service General Hospital

Chung-Ching Wang

Tri-Service General Hospital

Ching-Huang Lai ( $\nabla$ lgh@mail.ndmctsgh.edu.tw )

National defense medical center https://orcid.org/0000-0001-5097-8574

Research

Keywords: Welding fumes, Serum adiponectin, Metabolic syndrome, Weighted quantile sum

Posted Date: December 21st, 2021

DOI: https://doi.org/10.21203/rs.3.rs-1150249/v1

License: (c) (i) This work is licensed under a Creative Commons Attribution 4.0 International License.

Read Full License 


\section{Abstract}

Background: The influence of welding-associated air pollutants on workers' health is mainly regarded as a core issue in public health and occupational medicine. Previous studies have indicated that workers exposed to metal fumes had an increased risk of metabolic syndrome, which was correlated with decreased serum adiponectin levels. This study aimed to explore whether heavy metal exposure affects the concentration of adiponectin among welding workers.

Methods: The study participants were recruited from a shipyard with 31 office workers and 100 welding workers in 2015 . Urinary metal concentrations were measured by inductively coupled plasma-mass spectrometry. Serum adiponectin was measured by enzyme-linked immunosorbent assay. Inferential statistics on repeated measures were performed using generalized estimating equations (GEEs). A weighted quantile sum (WQS) regression model was conducted to examine the joint effect of the association of multimetal exposure with serum adiponectin.

Results: After adjustment for all confounding variables through a GEE analysis, significantly negative associations of numerous urinary metals with serum adiponectin were detected in the welding workers, including $\operatorname{Cr}(\beta=-0.088 ; 95 \% \mathrm{Cl}:-0.148,-0.027), \mathrm{Mn}(\beta=-0.174 ; 95 \% \mathrm{Cl}:-0.267,-0.081)$, $\operatorname{Co}(\beta=-0.094 ; 95 \%$ Cl: $-0.158,-0.029), \mathrm{Ni}(\beta=-0.108 ; 95 \% \mathrm{Cl}:-0.208,-0.008), \mathrm{Cd}(\beta=-0.067 ; 95 \% \mathrm{Cl}:-0.115,-0.018)$, and Pb ( $\beta$ $=-0.089 ; 95 \% \mathrm{Cl}:-0.163,-0.015)$. The contributions of multiple urinary metal levels to serum adiponectin levels, determined individually by WQS regression, suggested that $\mathrm{Pb}$ was the greatest contributor.

Conclusions: Welding workers exposed to heavy metals such as $\mathrm{Pb}, \mathrm{Cr}, \mathrm{Co}, \mathrm{Mn}, \mathrm{Ni}$, and $\mathrm{Cd}$ might have reduced serum adiponectin levels and an increased risk of cardiovascular disease.

\section{Background}

Welding is ubiquitous and indispensable in industrial development, and it consists of joining metals by fusing and melting them; it also includes tasks such as grinding, brazing, and soldering. It is estimated that more than 1 million workers worldwide perform welding as a part of their jobs [1]. Potential health hazards may arise during the welding process, including exposure to physical hazards, ergonomic stress, and chemical poisons. Among these health hazards, the influence of welding-associated air pollutants on workers' health is regarded as a core issue in public health and occupational medicine. Welding fumes are a byproduct of the process, and the rate of generation and the composition of welding fumes are characteristic of the different materials being welded and the soldering components used. Ultrafine and fine welding particles often consist of numerous metals, including iron $(\mathrm{Fe})$, lead $(\mathrm{Pb})$, zinc $(\mathrm{Zn})$, nickel $(\mathrm{Ni})$, copper $(\mathrm{Cu})$, manganese $(\mathrm{Mn})$, cobalt $(\mathrm{Co})$, cadmium $(\mathrm{Cd})$, and chromium $(\mathrm{Cr})$. The size of the welding particles generated differs based on the industrial processes undertaken. Earlier studies have indicated that welding particles are in the ultrafine size range of 0.01 to $0.10 \mu \mathrm{m}$ [2] and that most of the welding fumes have particles that are $<0.50 \mu \mathrm{m}$ in aerodynamic diameter [3]. Ultrafine particles have a 
higher likelihood of being deposited in the smaller branches of the bronchial airways in the respiratory tract; rapid clearance by the mucociliary system is much more ineffective.

A previous study indicated that welding fumes were known to cause acute pulmonary diseases, such as metal fume fever [4]. Moreover, several studies have reported the adverse impacts of welding fume exposure on the development of chronic health conditions, including pulmonary fibrosis [5], chronic obstructive pulmonary disease [6], and carcinogenesis [7]. At the same time, few studies have shown that long-term heavy metal exposure could raise the risk of developing metabolic syndrome (MetS) [8, 9], which is a constellation of cardiometabolic abnormalities and is recognized as a risk factor for cardiovascular disease and type 2 diabetes mellitus [10]. Additionally, a large cohort study that enrolled 10,059 male metal workers demonstrated that welding processed particles raised the risk of cardiovascular disease [11]. Previous studies have illustrated that the potential mechanisms by which metal fume exposure induces cardiometabolic illness might be correlated with systemic inflammation and the oxidative stress response $[12,13]$.

Adiponectin is an adipose-derived hormone that is abundantly present in human plasma; it is adversely modulated by the accumulation of visceral fat and is lowered in obesity. Thus, it plays an essential role as a vital messenger in the communication between metabolism-related organs and adipose tissue. Adiponectin is secreted into the circulation, where it exerts insulin-sensitizing, antiatherosclerotic, and anti-inflammatory effects. In addition, adiponectin can increase insulin sensitivity in the skeletal muscle and the liver, and it is associated with reducing atherosclerosis [14]. Aside from these effects, adiponectin seems to display pleiotropic impacts on MetS. Emerging studies have emphasized the role played by hypoadiponectinemia in the pathogenesis of insulin resistance, MetS, diabetes, and cardiovascular disease $[15,16]$.

Given the awareness of the possible factors controlling adiponectin levels, including genetic, dietary, and lifestyle factors and environmental interventions, limited studies have discussed the relationship between occupational exposure to metals and adiponectin levels. Because welding workers are exposed to multiple heavy metals simultaneously, the combined effects of different heavy metals have not been discussed in previous surveys. By way of weighted quantile sum (WQS) regression, we could assess the weights of environmental chemicals, which allowed us to make clinical assumptions regarding relative chemical importance. Therefore, we designed a longitudinal study to explore the association between welding fume exposure and serum adiponectin levels.

\section{Methods}

\section{Data source and participants}

We recruited the study subjects from a shipyard in northern Taiwan, and all qualified subjects were classified into two groups based on their job responsibilities in 2014. At baseline, there were 70 welding workers in the exposure group and 26 office workers in the control group. The following year, almost all 
the earlier participants were recruited and underwent the same study protocols; moreover, we also included new study subjects in both the exposure and control groups. Finally, in 2015, a total of 131 study participants qualified for this study, namely, 100 welding workers and 31 office workers. Additionally, we excluded female subjects and individuals with diabetes or those receiving antidiabetic agents, as we intended to eliminate the impacts of sex and metabolism as much as possible.

All workers were asked to fill out a self-administered questionnaire that contained demographic and personal information, including medical history, respiratory protective devices used, and lifestyle habits. Furthermore, all study participants underwent physical examinations, morning urine sample collection after one day of exposure between 8 AM and 5 PM with 1 hour of rest between 12 PM and 1 PM on Tuesday, and blood sampling after 8 hours of overnight fasting. Additionally, all workers were required to wear personal air samplers for a 1-day exposure on Monday. The Ethics Committee of the Tri-Service General Hospital-Joint Institutional Review Board approved this research. All individuals in this survey provided written informed consent.

\section{Measurement of field air sampling}

Personal air samples were collected by active samplers with filters of cellulose ester (pore size: $0.8 \mu \mathrm{m}$ and diameter: $37 \mathrm{~mm}$ ) from the workspaces of all participants; the active samplers had a flow rate of 2 $\mathrm{L} / \mathrm{min}$ to gather the heavy metals. All workers were required to carry these personal samplers, which were placed in the breathing zone of the participants for a full eight-hour working day. The levels of heavy metals were detected using inductively coupled plasma-mass spectrometry (ICP-MS, Agilent 7500ce, Agilent, Santa Clara, CA, USA).

\section{Assessment of urinary metal concentrations}

Morning urine samples were collected after one workday of exposure and stored at $-80^{\circ} \mathrm{C}$ until analysis. ICP-MS also measured the levels of urinary metals, and the procedures were performed twice as independent experiments. Each metal's interday and intraday coefficients of variation were within $5 \%$. In addition, urine creatinine was measured by Jaffe's method for adjusting urinary biomarker concentrations.

\section{Measurement of serum adiponectin levels}

Fasting blood samples were collected in EDTA-treated tubes by venipuncture based on standard protocols, kept on ice, and delivered to our laboratory for further assessment. After centrifugation, fractions were separated and kept on ice, snap-frozen in liquid nitrogen, and stored at $-80^{\circ} \mathrm{C}$ until analysis. Serum adiponectin was analyzed with a commercial enzyme-linked immunosorbent kit (ELISA) (Calbiotech, Inc., USA).

\section{Measurement of other covariates}

All participants underwent peripheral blood sampling after eight hours of overnight fasting to obtain cardiometabolic parameters, including triglycerides, total cholesterol, fasting glucose, serum albumin, and 
uric acid. Body mass index (BMI), expressed in kilograms by meters squared, was determined based on subjects' height and weight. As previously described, interviewer-assessment questionnaires were applied to acquire data on personal information and lifestyle factors.

\section{Statistical analysis}

Basic characteristics, biochemistry data, and metal biomarkers between the control group and exposure group were compared using Student's t tests for continuous variables and chi-squared tests for discrete variables. Generalized estimating equations (GEEs) on repeated measures were utilized to investigate the effectiveness of metal exposure in modulating serum adiponectin concentrations. Since urinary metals and serum adiponectin were not normally distributed, log transformation was utilized to achieve a normal distribution. GEEs with a first-order autoregressive working correlation matrix were conducted to model the study outcome while accounting for correlated data within the repeated measures of the study design. The changes in study outcome values from baseline to follow-up were expressed in the exposed and control groups under adjustment for potential confounding factors. The adjusted models compared both groups over time while accounting for age, BMI, serum albumin, total cholesterol, uric acid, fasting glucose, triglycerides, urine creatinine, job tenure, current smoking status, and exercise habits.

Moreover, a WQS regression model was conducted to examine the combined effects of the highly associated multimetal exposures with serum adiponectin. The WQS approach presumed that all metals had the same direction effects on the study outcome, regardless of positive or negative results [17]. A set of weights quantified the weights of the different influences of individual exposures. Each weight was confined within 0 and 1 , and all the weights were summed to 1 . WQS regression estimates were calculated from 1,000 bootstraps with the sample separated into validation and training datasets by a split proportion of 4:6. Statistical analysis was performed using IBM SPSS statistics software for Windows version 22.0 (IBM Corp., Armonk, NY, USA). Additionally, WQS regression was implemented by means of the gWQS package for $R$ 3.5.1. The definition of statistical significance was a two-sided $P$ value of $<0.05$.

\section{Results}

\section{Demographic and clinical characteristics of the subjects}

The ratios of the ambient air sampling of heavy metals for comparing the exposure and control groups are shown in Fig. 1. Fe was the most abundant metal, which displayed a 134.7-fold change following exposure, followed by $\mathrm{Mn}$ in decreasing order with an 81.9-fold change. All metals in the ambient air sampling showed higher concentrations in the exposure group to varying degrees. The demographic characteristics of all participants, including office and welding workers, are listed in Table 1. Compared with the office workers, the welding workers in this study were likely to be younger, had less job tenure, and had significantly lower blood albumin and higher urine creatinine levels. The mean ages of the office and welding workers were $52.74 \pm 12.28$ and $44.08 \pm 11.15$ years old, respectively. 
Table 1

Characteristics of welding and office workers at baseline

\begin{tabular}{|c|c|c|c|c|}
\hline & $\begin{array}{l}\text { Total } \\
\text { workers } \\
(n=96)\end{array}$ & $\begin{array}{l}\text { Welding workers } \\
(n=70)\end{array}$ & $\begin{array}{l}\text { Office } \\
\text { workers } \\
(n=26)\end{array}$ & $\begin{array}{l}p \\
\text { values }\end{array}$ \\
\hline \multicolumn{5}{|c|}{ Continuous variables } \\
\hline $\begin{array}{l}\text { Age } \\
\text { (years) }\end{array}$ & $46.43(12.04)$ & $44.08(11.15)$ & $52.74(12.28)$ & 0.001 \\
\hline BMI & $25.21(3.33)$ & $25.15(3.37)$ & $25.36(3.27)$ & 0.784 \\
\hline $\begin{array}{l}\text { Albumin } \\
(\mathrm{g} / \mathrm{dL})\end{array}$ & $4.71(0.21)$ & $4.74(0.21)$ & $4.62(0.19)$ & 0.011 \\
\hline $\begin{array}{l}\text { Total cholesterol } \\
(\mathrm{mg} / \mathrm{dL})\end{array}$ & $190.40(56.77)$ & $192.79(64.07)$ & $183.96(29.33)$ & 0.501 \\
\hline $\begin{array}{l}\text { Triglyceride } \\
(\mathrm{mg} / \mathrm{dL})\end{array}$ & $144.73(201.03)$ & $150.66(231.96)$ & $128.77(68.58)$ & 0.638 \\
\hline $\begin{array}{l}\text { Uric acid } \\
(\mathrm{mg} / \mathrm{dL})\end{array}$ & $6.69(1.50)$ & $6.68(1.56)$ & $6.70(1.32)$ & 0.952 \\
\hline $\begin{array}{l}\text { Fasting glucose } \\
(\mathrm{mg} / \mathrm{dL})\end{array}$ & $94.55(8.75)$ & $94.56(9.32)$ & $94.54(7.15)$ & 0.993 \\
\hline $\begin{array}{l}\text { Urine creatinine } \\
(\mathrm{mg} / \mathrm{dL})\end{array}$ & $133.82(72.36)$ & $143.53(76.32)$ & $107.70(53.36)$ & 0.030 \\
\hline $\begin{array}{l}\text { Job tenure } \\
\text { (years) }\end{array}$ & $22.75(15.40)$ & $20.75(15.28)$ & $28.12(14.70)$ & 0.037 \\
\hline $\begin{array}{l}\text { Adiponectin } \\
\text { (ug/dL) }\end{array}$ & $13.69(6.93)$ & $13.55(7.30)$ & $14.16(5.62)$ & 0.666 \\
\hline \multicolumn{5}{|c|}{ Categorical variables } \\
\hline Current Smoking & $49(51.0)$ & $39(55.7)$ & $10(38.5)$ & 0.170 \\
\hline \multicolumn{5}{|c|}{ BMI, body mass index. } \\
\hline \multicolumn{5}{|c|}{ a Values were expressed as mean (standard deviation) } \\
\hline b Values in the $\mathrm{c}$ & orical variables & expressed as & ber $(\%)$ & \\
\hline
\end{tabular}




\begin{tabular}{|lllll|}
\hline & $\begin{array}{l}\text { Total } \\
\text { workers } \\
(\mathbf{n = 9 6 )}\end{array}$ & $\begin{array}{l}\text { Welding workers } \\
(\mathbf{n}=70)\end{array}$ & $\begin{array}{l}\text { Office } \\
\text { workers } \\
(\mathbf{n}=\mathbf{2 6})\end{array}$ & $\begin{array}{l}\boldsymbol{p} \\
\text { values }\end{array}$ \\
\hline Current Exercise & $26(27.1)$ & $17(24.3)$ & $9(34.6)$ & 0.359 \\
\hline BMl, body mass index. & \\
\hline a Values were expressed as mean (standard deviation) & \\
\hline b Values in the categorical variables were expressed as number (\%) & \\
\hline
\end{tabular}

Nevertheless, these groups did not have significant differences in BMI, total cholesterol, triglycerides, uric acid, fasting glucose, or personal habits. In addition, all welding workers had used respiratory protective devices at work by self-report (data not shown). The comparison of urinary metals in the office and welding workers at baseline is shown in Table 2. Although there were no significant differences between the groups for all urinary metals, the concentration of urinary metals in the welding workers seemed to be higher than that in office workers. 
Table 2

The concentration of urinary metals in welding and office workers at baseline

\begin{tabular}{|c|c|c|c|c|}
\hline $\begin{array}{l}\text { Urinary } \\
\text { metals }\end{array}$ & $\begin{array}{l}\text { Total } \\
\text { Workers } \\
(n=96)\end{array}$ & $\begin{array}{l}\text { Welding workers } \\
(n=76)\end{array}$ & $\begin{array}{l}\text { Office } \\
\text { Workers } \\
(n=20)\end{array}$ & $\begin{array}{l}p \\
\text { values }\end{array}$ \\
\hline $\begin{array}{l}\text { Urine } \mathrm{Cr}^{\mathrm{a}} \\
(\mu \mathrm{g} / \mathrm{L})\end{array}$ & 89.99 (799.95) & $119.32(941.01)$ & $13.71(57.21)$ & 0.578 \\
\hline $\begin{array}{l}\text { Urine } \mathrm{Mn}^{\mathrm{a}} \\
(\mu \mathrm{g} / \mathrm{L})\end{array}$ & $28.96(229.42)$ & $36.44(269.27)$ & $9.53(35.90)$ & 0.621 \\
\hline $\begin{array}{l}\text { Urine } \mathrm{Co}^{\mathrm{a}} \\
(\mu \mathrm{g} / \mathrm{L})\end{array}$ & $1.42(5.88)$ & $1.58(6.88)$ & $0.99(1.17)$ & 0.675 \\
\hline $\begin{array}{l}\text { Urine } \mathrm{Ni}^{\mathrm{a}} \\
(\mu \mathrm{g} / \mathrm{L})\end{array}$ & $209.48(1652.45)$ & $266.66(1942.89)$ & $60.82(166.72)$ & 0.599 \\
\hline $\begin{array}{l}\text { Urine } Z \mathrm{n}^{\mathrm{a}} \\
(\mu \mathrm{g} / \mathrm{L})\end{array}$ & $601.06(560.91)$ & $631.57(619.45)$ & $521.72(366.60)$ & 0.408 \\
\hline $\begin{array}{l}\text { Urine } \mathrm{Cd}^{\mathrm{a}} \\
(\mu \mathrm{g} / \mathrm{L})\end{array}$ & $1.77(9.36)$ & $2.11(11.00)$ & $0.86(0.95)$ & 0.571 \\
\hline $\begin{array}{l}\text { Urine } \mathrm{Pb}^{\mathrm{a}} \\
(\mu \mathrm{g} / \mathrm{L})\end{array}$ & $32.92(10.16)$ & 33.37 (11.19) & $31.45(5.63)$ & 0.360 \\
\hline $\begin{array}{l}\text { Urine } \mathrm{Cu}^{\mathrm{a}} \\
(\mu \mathrm{g} / \mathrm{L})\end{array}$ & $150.45(265.48)$ & $157.13(311.22)$ & $133.07(51.46)$ & 0.703 \\
\hline
\end{tabular}

\section{Correlations of urinary metal levels with serum adiponectin}

The GEE results for the correlations among metal exposure and serum adiponectin are shown in Table 3. After full adjustment for age, BMl, albumin, total cholesterol, triglycerides, fasting glucose, uric acid, urine creatinine, job tenure, exercise habits, and current smoking status, significantly negative associations of numerous urinary metal levels with serum adiponectin concentration were detected among the welding workers, including $\mathrm{Cr}(\beta=-0.088 ; 95 \% \mathrm{Cl}:-0.148,-0.027, \mathrm{p}=0.004), \mathrm{Mn}(\beta=-0.174 ; 95 \% \mathrm{Cl}:-0.267,-0.081$, $p<0.001)$, Co $(\beta=-0.094 ; 95 \% \mathrm{Cl}:-0.158,-0.029, p=0.004)$, Ni $(\beta=-0.108 ; 95 \% \mathrm{Cl}:-0.208,-0.008, p=$ $0.033), \mathrm{Cd}(\beta=-0.067 ; 95 \% \mathrm{Cl}:-0.115,-0.018, \mathrm{p}=0.007)$, and $\mathrm{Pb}(\beta=-0.089 ; 95 \% \mathrm{Cl}:-0.163,-0.015, p=$ 
0.018). However, there were no significant associations between urinary metals and serum adiponectin among office workers. Taken together, these findings indicated that occupational exposure to specific metals might have an impact on the reduction in serum adiponectin levels.

Table 3

Association between urinary metal concentrations and serum adiponectin levels by generalized estimating equation

\begin{tabular}{|c|c|c|c|c|}
\hline \multirow{4}{*}{$\begin{array}{l}\text { Exposure } \\
\text { markers }\end{array}$} & \multirow{2}{*}{\multicolumn{2}{|c|}{$\begin{array}{l}\text { Welding workers } \\
\text { Serum adiponectin }(\log \mu \mathrm{g} / \mathrm{ml})\end{array}$}} & \multicolumn{2}{|l|}{ Office workers } \\
\hline & & & \multirow{3}{*}{$\begin{array}{l}\beta^{b} \\
(95 \% \mathrm{Cl})\end{array}$} & \multirow{3}{*}{$\begin{array}{l}\mathrm{p} \\
\text { value }\end{array}$} \\
\hline & $\beta^{\mathrm{b}}$ & $\mathbf{p}$ & & \\
\hline & $(95 \% \mathrm{Cl})$ & value & & \\
\hline \multirow{2}{*}{$\begin{array}{l}\text { Urine } \mathrm{Cr}^{\mathrm{a}} \\
(\log \mu \mathrm{g} / \mathrm{L})\end{array}$} & -0.088 & 0.004 & 0.022 & 0.695 \\
\hline & \multicolumn{2}{|l|}{$(-0.148,-0.027)$} & \multicolumn{2}{|l|}{$(-0.088,0.133)$} \\
\hline \multirow{2}{*}{$\begin{array}{l}\text { Urine } \mathrm{Mn}^{\mathrm{a}} \\
(\log \mu \mathrm{g} / \mathrm{L})\end{array}$} & -0.174 & $<0.001$ & 0.020 & 0.776 \\
\hline & \multicolumn{2}{|l|}{$(-0.267,-0.081)$} & \multicolumn{2}{|l|}{$(-0.116,0.156)$} \\
\hline \multirow{2}{*}{$\begin{array}{l}\text { Urine } \mathrm{Co}^{\mathrm{a}} \\
(\log \mu \mathrm{g} / \mathrm{L})\end{array}$} & -0.094 & 0.004 & 0.017 & 0.731 \\
\hline & \multicolumn{2}{|l|}{$(-0.158,-0.029)$} & \multicolumn{2}{|l|}{$(-0.082,0.116)$} \\
\hline \multirow{2}{*}{$\begin{array}{l}\text { Urine } \mathrm{Ni}^{\mathrm{a}} \\
(\log \mu \mathrm{g} / \mathrm{L})\end{array}$} & -0.108 & 0.033 & -0.004 & 0.956 \\
\hline & \multicolumn{2}{|l|}{$(-0.208,-0.008)$} & \multicolumn{2}{|l|}{$(-0.157,0.148)$} \\
\hline \multirow{2}{*}{$\begin{array}{l}\text { Urine } \mathrm{Zn}^{\mathrm{a}} \\
(\log \mu \mathrm{g} / \mathrm{L})\end{array}$} & -0.095 & 0.112 & -0.030 & 0.677 \\
\hline & \multicolumn{2}{|l|}{$(-0.213,0.022)$} & \multicolumn{2}{|l|}{$(-0.173,0.112)$} \\
\hline \multirow{2}{*}{$\begin{array}{l}\text { Urine } \mathrm{Cu}^{\mathrm{a}} \\
(\log \mu \mathrm{g} / \mathrm{L})\end{array}$} & -0.025 & 0.800 & -0.127 & 0.533 \\
\hline & \multicolumn{2}{|l|}{$(-0.214,0.165)$} & \multicolumn{2}{|l|}{$(-0.273,0.527)$} \\
\hline \multirow{2}{*}{$\begin{array}{l}\text { Urine } \mathrm{Cd}^{\mathrm{a}} \\
(\log \mu \mathrm{g} / \mathrm{L})\end{array}$} & -0.067 & 0.007 & 0.007 & 0.850 \\
\hline & \multicolumn{2}{|l|}{$(-0.115,-0.018)$} & \multicolumn{2}{|l|}{$(-0.068,0.083)$} \\
\hline Urine $\mathrm{Pb}^{\mathrm{a}}$ & -0.089 & 0.018 & 0.029 & 0.554 \\
\hline$(\log \mu \mathrm{g} / \mathrm{L})$ & \multicolumn{2}{|l|}{$(-0.163,-0.015)$} & \multicolumn{2}{|l|}{$(-0.068,0.126)$} \\
\hline \multicolumn{5}{|c|}{$\begin{array}{l}\text { a Adjusted covariates including age, BMI, serum albumin, total cholesterol, uric acid, fasting glucose } \\
\text { triglyceride, urine creatinine, job tenure, smoking habit, recreational activity. }\end{array}$} \\
\hline $\begin{array}{l}\mathrm{b} \beta \text { coefficie } \\
\text { metal conce }\end{array}$ & erpreted as a ch & adipc & vel for each ir & rinary \\
\hline
\end{tabular}




\section{The contributions of multiple metal exposures to serum adiponectin}

Table 4 illustrates an estimate of $-0.0435(p=0.048)$ per WQS unit in the unadjusted model and an estimate of $-0.0478(p=0.026)$ per WQS unit in the adjusted model in the inverse correlation. The contributions of multiple urinary metal levels to serum adiponectin levels individually by the WQS regression model are illustrated in Fig. 2. As displayed in Fig. 2A, the highest contributors to serum adiponectin were $\mathrm{Pb}, \mathrm{Mn}, \mathrm{Ni}, \mathrm{Cd}, \mathrm{Cr}$, and $\mathrm{Co}$, making up $49.4 \%, 22.4 \%, 15.3 \%, 6.3 \%, 5.3 \%$, and $1.4 \%$ of the total contribution, respectively, in the unadjusted model. Among these metal exposures, $\mathrm{Pb}$ and $\mathrm{Mn}$ were the crucial influencing factors. After adjusting for confounders in the WQS regression model, an inverse association was found between urinary heavy metals and serum adiponectin. Fig. 2B shows that $\mathrm{Pb}, \mathrm{Co}$, and $\mathrm{Cr}$ were $30.9 \%, 27.2 \%$, and $25.7 \%$ contributors to serum adiponectin, respectively. Collectively speaking, regardless of these unadjusted or adjusted WQS regression models, among metal exposures, $\mathrm{Pb}$ was the most negative contributor and had the greatest influence on serum adiponectin levels.

Table 4

$\beta$ coefficients from the weighted quantile sum (WQS) regressions for serum adiponectin levels

\begin{tabular}{|c|c|c|c|c|c|c|c|c|}
\hline & & & Weight & & & & & \\
\hline & coefficients & value & $\log \mathrm{Pb}$ & $\log M n$ & $\log \mathrm{Ni}$ & $\log C d$ & $\log \mathrm{Cr}$ & $\log C_{0}$ \\
\hline Unadjusted & -0.0435 & 0.048 & 49.4 & 22.4 & 15.3 & 6.3 & 5.3 & 1.4 \\
\hline Adjusted & -0.0478 & 0.026 & 30.9 & 8.6 & 2.1 & 5.5 & 25.7 & 27.2 \\
\hline
\end{tabular}

\section{Discussion}

In this two-year longitudinal study, the most prominent finding was that occupational exposure to specific metals was negatively linked to serum adiponectin levels in welding workers. Additionally, among heavy metal exposures by WQS regression analyses, $\mathrm{Pb}$ was the most negative contributor to serum adiponectin levels. To the best of our knowledge, this study was the first to examine the impacts of occupational metal exposure on serum adiponectin levels using GEE and WQS regression models.

An earlier study reported occupational and environmental exposure to $\mathrm{Pb}$ as a probable risk factor for cardiovascular disease [18]. Recent experimental and epidemiological studies have indicated that heavy metal exposure was considered a risk factor for cardiovascular disease and raised the public health burden [19-21]. These review articles discussed the potential correlation between chronic heavy metal exposure-including exposure to $\mathrm{Pb}, \mathrm{Cd}$, mercury $(\mathrm{Hg})$, and arsenic (As)-and cardiovascular disease, although the mechanism through which heavy metals act to elevate cardiovascular risks remains disputed. These nonessential heavy metals were all nonthreshold toxins and could display toxic effects 
at trace concentrations [22]. A review article by Xu et al. proposed that exposure to increased levels of As, $\mathrm{Cd}, \mathrm{Pb}$, and $\mathrm{Hg}$ was significantly correlated with MetS or comorbid conditions [23]. Another crosssectional study analysis derived from the Korea National Health and Nutrition Examination Survey of 1,405 subjects indicated that a higher prevalence of MetS was correlated with increased blood $\mathrm{Pb}$ concentrations in Koreans [24]. Additionally, a prospective cohort study that enrolled 2,500 young adults of African descent reported that blood $\mathrm{As}$ and $\mathrm{Pb}$ were significantly associated with elevated fasting glucose with adjustment for percent body fat [25]. In 2000, a review article that contained cell, animal, and human study results suggested the damaging role of $\mathrm{Cd}$ in the organic impairment of glucose metabolism; therefore, it contributed to insulin resistance [26]. Numerous studies have established the adverse impacts of toxic heavy metals as potential biomarkers for developing cardiometabolic illnesses.

However, limited literature has explored the relationship between heavy metals and adiponectin levels, especially in occupational exposure. An animal/mouse model executed by Kawakami et al. revealed that Cd exposure caused abnormal adipocyte differentiation, expansion, and function, which lowered the gene expression levels of adiponectin and might contribute to insulin insensitivity [27]. In 2013, the same study group designed another mouse model with $\mathrm{Cd}$ administration, which also indicated that $\mathrm{Cd}$ exposure induced abnormally smaller adipocytes and decreased adiponectin levels [28]. Another mouse model by the same author found that in vivo exposure to inorganic Co might exhibit a protective function in obesity-related diseases by increasing the expression of adiponectin [29]. This finding was inconsistent with our study results, which demonstrated that occupational exposure to Co might reduce serum adiponectin levels in welding workers. Apart from the animal studies, a longitudinal study by Wang and his colleagues that enrolled 1,228 midlife women without specific heavy metal exposure illustrated that exposure to $\mathrm{Cd}$ was associated with an adverse adiponectin profile [30]. Taken together, exposure to $\mathrm{Cd}$ was reported as a negative influencing factor on the expression levels of adiponectin, and based on the few studies available, it might also worsen insulin sensitivity and lead to the development of diabetes. In line with earlier reports, our study results revealed that $\mathrm{Cd}$ exposure was correlated with decreased serum adiponectin levels, while Co exposure also demonstrated a negative adiponectin profile.

Our preceding study reported that $\mathrm{Fe}, \mathrm{Zn}, \mathrm{Mn}$, and $\mathrm{Cu}$ were dominant among the welding fumes in a shipyard and that welding workers had higher urinary concentrations of $\mathrm{Co}, \mathrm{Cu}, \mathrm{Ni}, \mathrm{Mn}, \mathrm{Cd}$, and $\mathrm{Zn}$ [31]. Thus, we selected the eight metals to test for in the postexposure urinary samples of the participants in this survey. Among these heavy metal exposures, $\mathrm{Pb}$ had the most negative influence on serum adiponectin levels according to the WQS model. One of the mechanisms was probably related to lipid disturbance in occupational $\mathrm{Pb}$ exposure. An earlier cross-sectional study by Ademuyiwa et al. suggested that $\mathrm{Pb}$ exposure increased cholesterol synthesis and transport to peripheral tissues among petrol station workers [32]. Additionally, aside from conventional mechanisms, telomere shortening and lipid disturbance were also regarded as unignorable roles in the pathway whereby low-level $\mathrm{Pb}$ exposure contributed to cardiovascular disease [33]. Moreover, a cross-sectional study of 986 subjects by Sirivarasai et al. indicated that exposure to low Pb levels correlated with deficiency of the enzyme catalase and oxidative stress, which might lead to high blood pressure [34]. In addition to toxic heavy metals, occupational exposure to some essential metals, such as $\mathrm{Co}, \mathrm{Ni}, \mathrm{Cr}$, and $\mathrm{Mn}$, also negatively 
affected serum adiponectin levels in our study. Generally, essential metals are necessary for proper cellular growth and function; otherwise, they play a crucial role as cofactors in various enzymes engaged in metabolism and energy production and respond to oxidative stress. Nevertheless, long-standing overexposure to and deficiencies in trace micronutrients could cause adverse health outcomes. Exposure to $\mathrm{Mn}, \mathrm{Ni}, \mathrm{Cr}$, and $\mathrm{Co}$ has increased because of their use as industrial metals in commercial applications over the last century. A recent study summarized that the main detrimental health impact of $\mathrm{Mn}, \mathrm{Ni}$, and Co, to a lesser extent, was on lipid peroxidation arising from oxidative stress [35]. Cr had multiple oxidation states ranging from -2 to +6 , in which the trivalent and hexavalent forms were primarily stable structures. $\mathrm{Cr}(\mathrm{VI})$ was connected with toxicity and carcinogenicity, while $\mathrm{Cr}(\mathrm{III})$ was essential in trace amounts for protein and lipid metabolism and acted as a cofactor for insulin action [36]. Similar to other metals, $\mathrm{Cr}(\mathrm{VI})$-induced oxidative stress and reactive oxygen species production at high concentrations affected the lipid content and DNA of cells, which resulted in lipid peroxidation and DNA damage, respectively [37]. Taken together, the typical negative health effects of exposure to heavy metals seemed to be lipid peroxidation resulting from oxidative stress, although heavy metals could also disturb metabolic functions in various ways.

Some limitations of this study should be considered. First, all welding workers were asked to use respiratory protective devices at work, but office workers were not compelled to wear masks whey they were in the shipyard. Therefore, some office workers might have contacted metal fumes during their workdays if they walked through the welding sites; this might have increased the exposure levels to heavy metals among the office workers more than we expected. Second, to eliminate sampling bias, we confined the work experience of office workers to those who had not held welding jobs within the past two years. However, some office workers in the shipyard had worked in the welding department when they were younger; therefore, the potential effects of earlier exposures to heavy metals on serum adiponectin levels could not be thoroughly assessed, although we corrected the covariates of job tenures. Next, some heavy metals, such as $\mathrm{Cr}$, had multiple oxidation states, but urinary metals analyzed in this study by ICPMS could not distinguish the amounts of individual oxidation states. Additionally, the welding aerosol composition varied depending on the specific type of welding process and materials used. Nevertheless, the work content of welding workers in this study could not be set up as a uniform welding process. Last, we did not include individual food intake or record dietary recall as confounding variables in this study. However, almost all workers obtained their lunch from factory-provided meals, which diminished the individual differences in the food consumption of the study subjects.

\section{Conclusions}

In conclusion, our study findings suggest that exposure to heavy metals decreases serum adiponectin levels in welding workers. Furthermore, $\mathrm{Pb}$ acted as the highest adverse contributor to lower adiponectin levels. Thus, we highlighted an important issue in the prevention of cardiometabolic diseases and occupational illnesses that deserves public attention. In the future, more basic research is needed to clarify the disease pathology and cellular and molecular pathways involved. 


\section{Declarations}

\section{Authors' Contributions}

Chen-Jung Wu contributed to the design of the study, was responsible for the management and retrieval of data, contributed to initial data analysis and interpretation, drafted the initial manuscript. Chen-Jung Wu, A-Chuan Ho, Shih-Ya Chen, Chih-Hong Pan, Hsiao-Chi Chuang, Wei-Liang Chen, and Chung-Ching Wang decided upon the data collection methods. Chen-Jung Wu and Ching-Huang Lai were also responsible for the data analysis decisions. Ching-Huang Lai conceptualized and designed the study, supervised all aspects of the study, critically reviewed and revised the manuscript, and approved the final manuscript as submitted. All authors meet the ICMJE criteria for authorship.

\section{Funding}

This study was supported in part by grants from the Ministry of Science and Technology (MOST 1032314-B-016 -007 to Ching-Huang Lai) in Taiwan.

\section{Acknowledgements}

We thank the funding from the Ministry of Science and Technology in Taiwan.

\section{Ethics approval and consent to participate}

The study was conducted according to the guidelines of the Declaration of Helsinki, and approved by the Institutional Review Board of Tri-Service General Hospital (TSGH) (IRB No 1-102-05-013). Informed consent was obtained from all subjects involved in the study.

\section{Consent for publication}

Not applicable.

\section{Conflict of interest}

The authors declared that they had no competing interests.

\section{References}

1. Antonini JM: Health effects of welding. Critical reviews in toxicology 2003, 33(1):61-103. 
2. Antonini JM, Lewis AB, Roberts JR, Whaley DA: Pulmonary effects of welding fumes: review of worker and experimental animal studies. American journal of industrial medicine 2003, 43(4):350360.

3. Akselsson KR, Desaedeleer GG, Johansson TB, Winchester JW: Particle size distribution and human respiratory deposition of trace metals in indoor work environments. The Annals of occupational hygiene 1976, 19(3-4):225-238.

4. Wardhana, Datau EA: Metal fume fever among galvanized welders. Acta medica Indonesiana 2014, 46(3):256-262.

5. Cosgrove MP: Pulmonary fibrosis and exposure to steel welding fume. Occupational medicine (Oxford, England) 2015, 65(9):706-712.

6. Koh DH, Kim Jl, Kim KH, Yoo SW: Welding fume exposure and chronic obstructive pulmonary disease in welders. Occupational medicine (Oxford, England) 2015, 65(1):72-77.

7. Zeidler-Erdely PC, Falcone LM, Antonini JM: Influence of welding fume metal composition on lung toxicity and tumor formation in experimental animal models. Journal of occupational and environmental hygiene 2019, 16(6):372-377.

8. Planchart A, Green A, Hoyo C, Mattingly CJ: Heavy Metal Exposure and Metabolic Syndrome: Evidence from Human and Model System Studies. Current environmental health reports 2018, 5(1):110-124.

9. Bulka CM, Persky VW, Daviglus ML, Durazo-Arvizu RA, Argos M: Multiple metal exposures and metabolic syndrome: A cross-sectional analysis of the National Health and Nutrition Examination Survey 2011-2014. Environmental research 2019, 168:397-405.

10. Aguilar M, Bhuket T, Torres S, Liu B, Wong RJ: Prevalence of the metabolic syndrome in the United States, 2003-2012. Jama 2015, 313(19):1973-1974.

11. Ibfelt E, Bonde JP, Hansen J: Exposure to metal welding fume particles and risk for cardiovascular disease in Denmark: a prospective cohort study. Occupational and environmental medicine 2010, 67(11):772-777.

12. Luo JC, Hsu KH, Shen WS: Inflammatory responses and oxidative stress from metal fume exposure in automobile welders. Journal of occupational and environmental medicine 2009, 51(1):95-103.

13. Brand P, Bauer M, Gube M, Lenz K, Reisgen U, Spiegel-Ciobanu VE, Kraus T: Relationship between welding fume concentration and systemic inflammation after controlled exposure of human subjects with welding fumes from metal inert gas brazing of zinc-coated materials. Journal of occupational and environmental medicine 2014, 56(1):1-5.

14. Kadowaki T, Yamauchi T: Adiponectin and adiponectin receptors. Endocrine reviews 2005, 26(3):439-451.

15. Lara-Castro C, Fu Y, Chung BH, Garvey WT: Adiponectin and the metabolic syndrome: mechanisms mediating risk for metabolic and cardiovascular disease. Current opinion in lipidology 2007, 18(3):263-270. 
16. Kadowaki T, Yamauchi T, Kubota N, Hara K, Ueki K, Tobe K: Adiponectin and adiponectin receptors in insulin resistance, diabetes, and the metabolic syndrome. The Journal of clinical investigation 2006, 116(7):1784-1792.

17. Carrico C, Gennings C, Wheeler DC, Factor-Litvak P: Characterization of Weighted Quantile Sum Regression for Highly Correlated Data in a Risk Analysis Setting. Journal of agricultural, biological, and environmental statistics 2015, 20(1):100-120.

18. Poręba R, Gać P, Poręba M, Andrzejak R: Environmental and occupational exposure to lead as a potential risk factor for cardiovascular disease. Environmental toxicology and pharmacology 2011, 31(2):267-277.

19. Alissa EM, Ferns GA: Heavy metal poisoning and cardiovascular disease. Journal of toxicology 2011, 2011:870125.

20. Burroughs Peña MS, Rollins A: Environmental Exposures and Cardiovascular Disease: A Challenge for Health and Development in Low- and Middle-Income Countries. Cardiology clinics 2017, 35(1):71-86.

21. Yang AM, Lo K, Zheng TZ, Yang JL, Bai YN, Feng YQ, Cheng N, Liu SM: Environmental heavy metals and cardiovascular diseases: Status and future direction. Chronic diseases and translational medicine 2020, 6(4):251-259.

22. Rahman Z, Singh VP: The relative impact of toxic heavy metals (THMs) (arsenic (As), cadmium (Cd), chromium $(\mathrm{Cr})(\mathrm{Vl})$, mercury $(\mathrm{Hg})$, and lead $(\mathrm{Pb})$ ) on the total environment: an overview. Environmental monitoring and assessment 2019, 191(7):419.

23. Xu P, Liu A, Li F, Tinkov AA, Liu L, Zhou JC: Associations between metabolic syndrome and four heavy metals: A systematic review and meta-analysis. Environmental pollution (Barking, Essex. 1987) 2021, 273:116480.

24. Rhee SY, Hwang YC, Woo JT, Sinn DH, Chin SO, Chon S, Kim YS: Blood lead is significantly associated with metabolic syndrome in Korean adults: an analysis based on the Korea National Health and Nutrition Examination Survey (KNHANES), 2008. Cardiovascular diabetology 2013, 12:9.

25. Ettinger AS, Bovet P, Plange-Rhule J, Forrester TE, Lambert EV, Lupoli N, Shine J, Dugas LR, Shoham D, Durazo-Arvizu RA et al: Distribution of metals exposure and associations with cardiometabolic risk factors in the "Modeling the Epidemiologic Transition Study". Environmental health: a global access science source 2014, 13:90.

26. Buha A, Đukić-Ćosić D, Ćurčić M, Bulat Z, Antonijević B, Moulis JM, Goumenou M, Wallace D: Emerging Links between Cadmium Exposure and Insulin Resistance: Human, Animal, and Cell Study Data. Toxics 2020, 8(3).

27. Kawakami T, Sugimoto H, Furuichi R, Kadota Y, Inoue M, Setsu K, Suzuki S, Sato M: Cadmium reduces adipocyte size and expression levels of adiponectin and Peg1/Mest in adipose tissue. Toxicology 2010, 267(1-3):20-26.

28. Kawakami T, Nishiyama K, Kadota Y, Sato M, Inoue M, Suzuki S: Cadmium modulates adipocyte functions in metallothionein-null mice. Toxicology and applied pharmacology 2013, 272(3):625- 
636.

29. Kawakami T, Hanao N, Nishiyama K, Kadota Y, Inoue M, Sato M, Suzuki S: Differential effects of cobalt and mercury on lipid metabolism in the white adipose tissue of high-fat diet-induced obesity mice. Toxicology and applied pharmacology 2012, 258(1):32-42.

30. Wang X, Karvonen-Gutierrez CA, Mukherjee B, Herman WH, Park SK: Urinary metals and adipokines in midlife women: The Study of Women's Health Across the nation (SWAN). Environmental research 2021, 196:110426.

31. Lai CY, Lai CH, Chuang HC, Pan CH, Yen CC, Lin WY, Chen JK, Lin LY, Chuang KJ: Physicochemistry and cardiovascular toxicity of metal fume PM2.5: a study of human coronary artery endothelial cells and welding workers. Scientific reports 2016, 6:33515.

32. Ademuyiwa O, Ugbaja RN, Idumebor F, Adebawo O: Plasma lipid profiles and risk of cardiovascular disease in occupational lead exposure in Abeokuta, Nigeria. Lipids in health and disease 2005, 4:19.

33. He L, Chen Z, Dai B, Li G, Zhu G: Low-level lead exposure and cardiovascular disease: the roles of telomere shortening and lipid disturbance. The Journal of toxicological sciences 2018, 43(11):623630.

34. Sirivarasai J, Kaojarern S, Chanprasertyothin S, Panpunuan P, Petchpoung K, Tatsaneeyapant A, Yoovathaworn K, Sura T, Kaojarern S, Sritara P: Environmental lead exposure, catalase gene, and markers of antioxidant and oxidative stress relation to hypertension: an analysis based on the EGAT study. BioMed research international 2015, 2015:856319.

35. Sule K, Umbsaar J, Prenner EJ: Mechanisms of $\mathrm{Co}$, Ni, and Mn toxicity: From exposure and homeostasis to their interactions with and impact on lipids and biomembranes. Biochimica et biophysica acta Biomembranes 2020, 1862(8):183250.

36. Balali-Mood M, Naseri K, Tahergorabi Z, Khazdair MR, Sadeghi M: Toxic Mechanisms of Five Heavy Metals: Mercury, Lead, Chromium, Cadmium, and Arsenic. Frontiers in pharmacology 2021, 12:643972.

37. Wise SS, Aboueissa AE, Martino J, Wise JP, Sr.: Hexavalent Chromium-Induced Chromosome Instability Drives Permanent and Heritable Numerical and Structural Changes and a DNA RepairDeficient Phenotype. Cancer research 2018, 78(15):4203-4214.

\section{Figures}




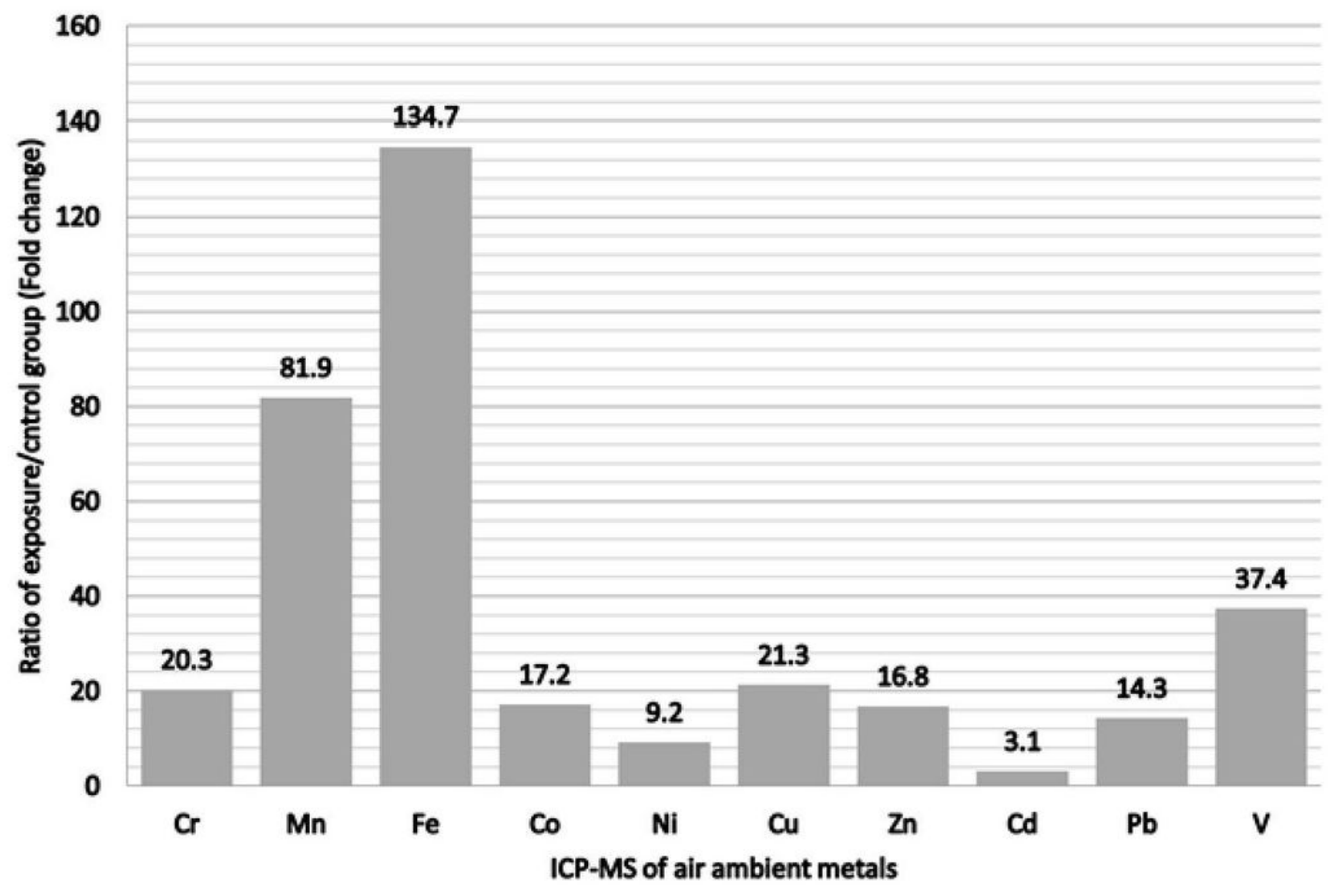

Figure 1

Ratio of metals of exposure/control group from personal air samples in the metal fumes particulate matter 
(A)

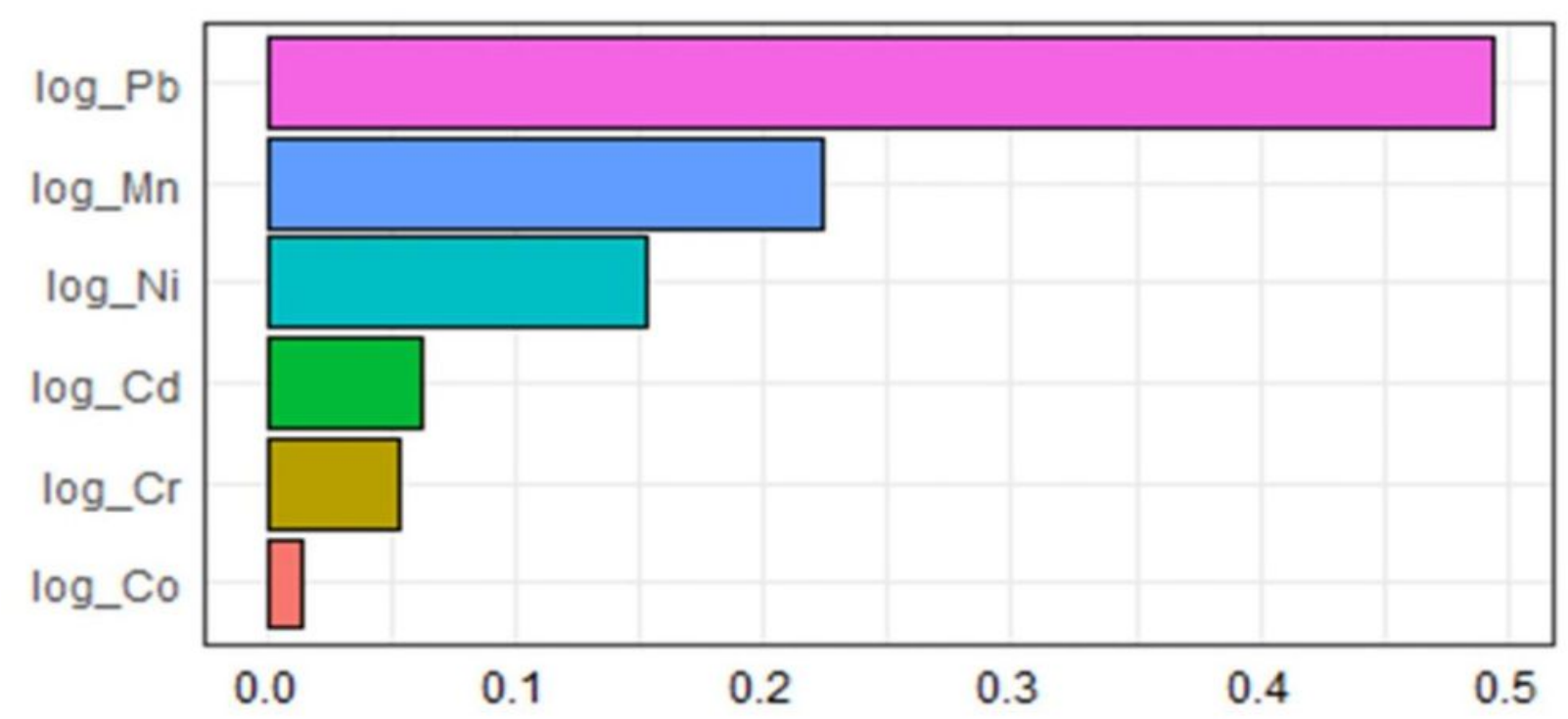

(B)

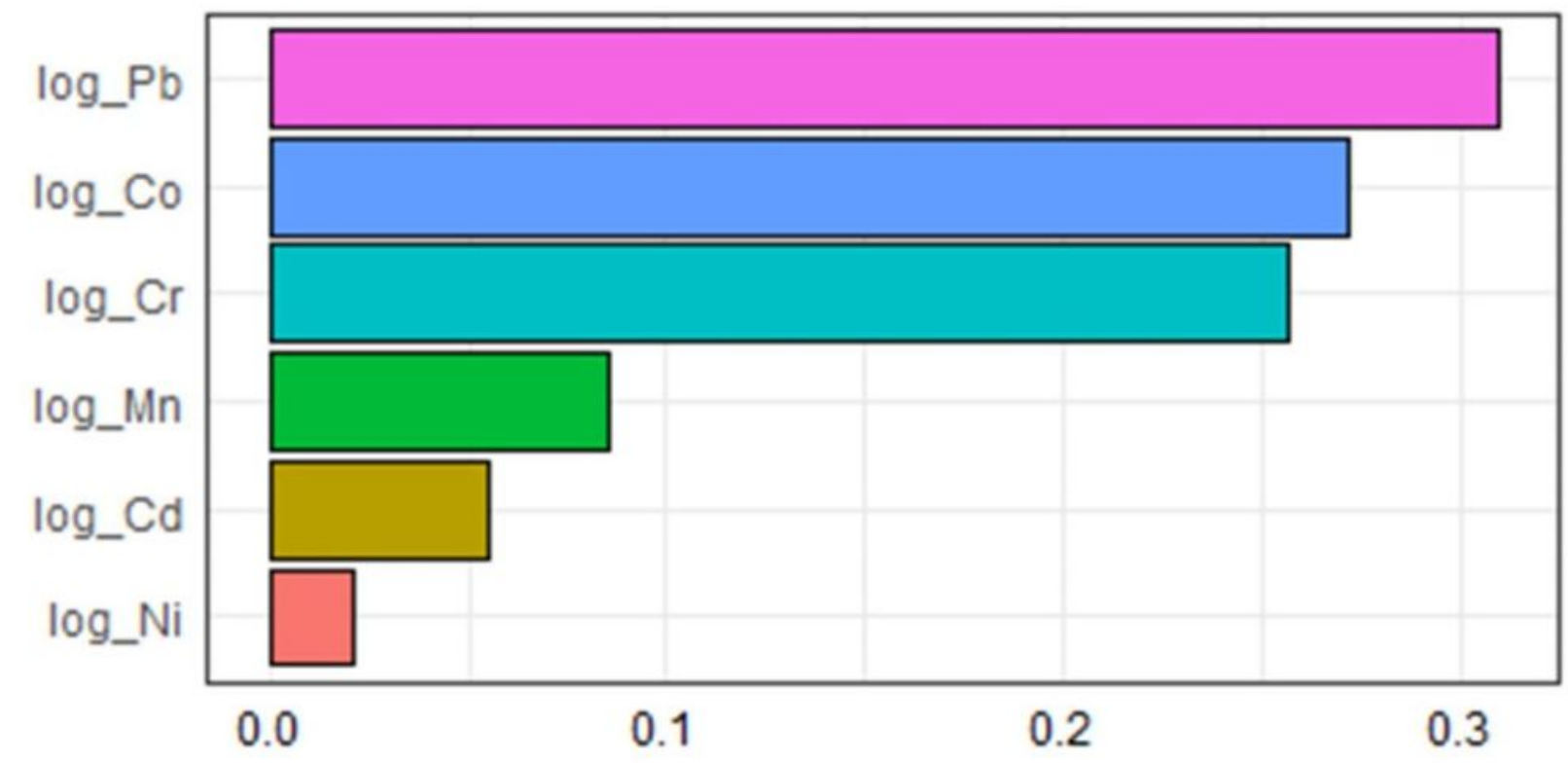

Figure 2

The associations between urinary metal levels and serum adiponectin levels based on weighted quantile sum regression analysis (A) unadjusted, (B) adjusted. 